\title{
Pelatihan Pembuatan Deterjen Cair Bagi lbu PKK Gampong Sungai Pauh Pusaka
}

\author{
Rizky Nafaida ${ }^{1}$, Fadlia ${ }^{2}$ dan Nursamsu ${ }^{3^{*}}$ \\ 1-3Universitas Samudra \\ ${ }^{*}$ Corresponding author \\ E-mail: samsu_bio@unsam.ac.id
}

\section{Article History:}

Received: 22-10-2020

Revised: 05-01-2021

Accepted: 05-01-2021

Keywords:

\section{Pendahuluan}

Gampong Sungai Pauh Pusaka berasal dari pemekaran Gampong Sungai Pauh yang dimekarkan menjadi 4 (empat) Gampong dari Sungai Pauh yaitu Sungai Pauh, Sungai Pauh Pusaka, Sungai Pauh Firdaus dan Sungai Pauh Tanjung. Jarak Universitas Samudra dengan Gampong Sungai Pauh Pusaka 6 km, ini merupakan sebagai salah satu gampong yang akan di laksanakan kegiatan pengabdian kepada masyarakat. Keberadaan sungai pauh pusaka sangat mendukung dengan kegiatan pengabdian kami, disebabkan gampong itu mempunyai masyarakat khususnya ibu ibu yang tidak mempunyai penghasilan untuk membantu keuangan tambahan keperluan rumah tangga. Sebab itulah kami akan membuat kegiatan pengabdian di Gampong Sungai Pauh Pusaka. Ditambah lagi kita sedang menghadapi musibah pandemic Covid 19 yang telah menyebar ke berbagai daerah, termasuk daerah kita provinsi Aceh. 
Peran warga gampong untuk pencegahan penyebaran virus Covid 19 sangat diperlukan. Dalam hal ini pengabdian kami menggandeng mitra ibu - ibu PKK Sungai Pauh. Peran ibu PKK dianggap sangat efektif untuk upaya pencegahan, karena para ibu akan bergerak ke institusi paling dasar, yaitu rumah tangga. Pelatihan pembuatan deterjen cair sangat berguna untuk para ibu, disamping sebagai cara untuk berwirausaha, deterjen cair juga bisa digunakan di level rumah tangga. Hal ini dikarenakan deterjen cair lebih mudah cara menanganinya dan lebih praktis dalam penggunaannya (Utomo et al., 2018).

Menurut penelitian Veenstra (1995) diketahui secara teoritis, hasil deterjen merupakan salah satu bahan yang mengandung surfaktan yang memiliki sifat dapat menurunkan tegangan permukaan, sehingga digunakan sebagai bahan pembersih kotoran yang menempel pada benda (Ramaswamy \& Veenstra, 1995). Namun, saat ini alkil benzen sulfonat sudah banyak digantikan dengan alkil linear benzen sulfonat maupun natrium lauril sulfat yang dianggap lebih mudah terdegradasi (Rosariawari, 2008).

Keinginan masyarakat untuk meningkatkan kualitas hidup terus meningkat. Berbagai produk baru dengan kualitas yang semakin baik terus bermunculan untuk memenuhi kebutuhan masyarakat. Deterjen merupakan produk yang digunakan masyarakat untuk melakukan kegiatan mencuci pakaian. Dalam masa pandemic ini deterjen adalah bahan yang efektif untuk mencegah penyebaran virus dengan seringnya kita mencuci pakaian. Dan juga detergen merupakan produk yang banyak digunakan masyarakat sebagai produk pembersih pakaian.

Sebagai wujud kepedulian kami terhadap pencegahan penyebaran Covid 19 dan pentingnya pola hidup bersih melalui deterjen baik di level rumah tangga dan wirausaha, maka tim pengabdian memberikan pelatihan kepada masyarakat khususnya ibu rumah tangga dengan judul: "Pelatihan Pembuatan Deterjen Cair Bagi Ibu PKK Gampong Sungai Pauh Pusaka.

Persoalan yang dihadapi terhadap permasalahan dalam pelaksanaan kegiatan pengabdian yaitu (a) Tidak adanya pengetahuan masyarakat untuk membuat deterjen cair; (b) Tidak ada pelatihan bagi masyarakat khususnya bagi ibu rumah tangga tentang pengetahuan keterampilan yang menjadikan peluang usaha home industri. Dari hasil telaah permasalahan yang dihadapi, maka solusi yang dapat diusulkan untuk menyelesaikan permasalahan yang dihadapi sebagai berikut: (a) Meningkatkan pengetahuan dan keterampilan ibu rumah tangga dalam mengolah deterjen cair; (b) Upaya peningkatan pendapatan penghasilan tambahan masyarakat, Membantu pemerintah desa untuk memajukan kesejahteraan masyarakat dan mensosialisasikan hasil proses pembuatan produk melalui media konvensional dan online. 


\section{Metode}

Pelaksanaan kegiatan pengabdian ini dilaksanakan mulai waktu pada bulan Agustus - September 2020. Tempat lokasi pengabdian dilaksanakan Gampong Sungai Pauh Pusaka Kecamatan Langsa Barat Kota Langsa.

Proses pelaksanaan kegiatan pengabdian dapat terdiri dari beberapa langkah yang meliputi (1) Survey; (2) Pelatihan pembuatan deterjen cair; (3) Monitoring dan Evaluasi.

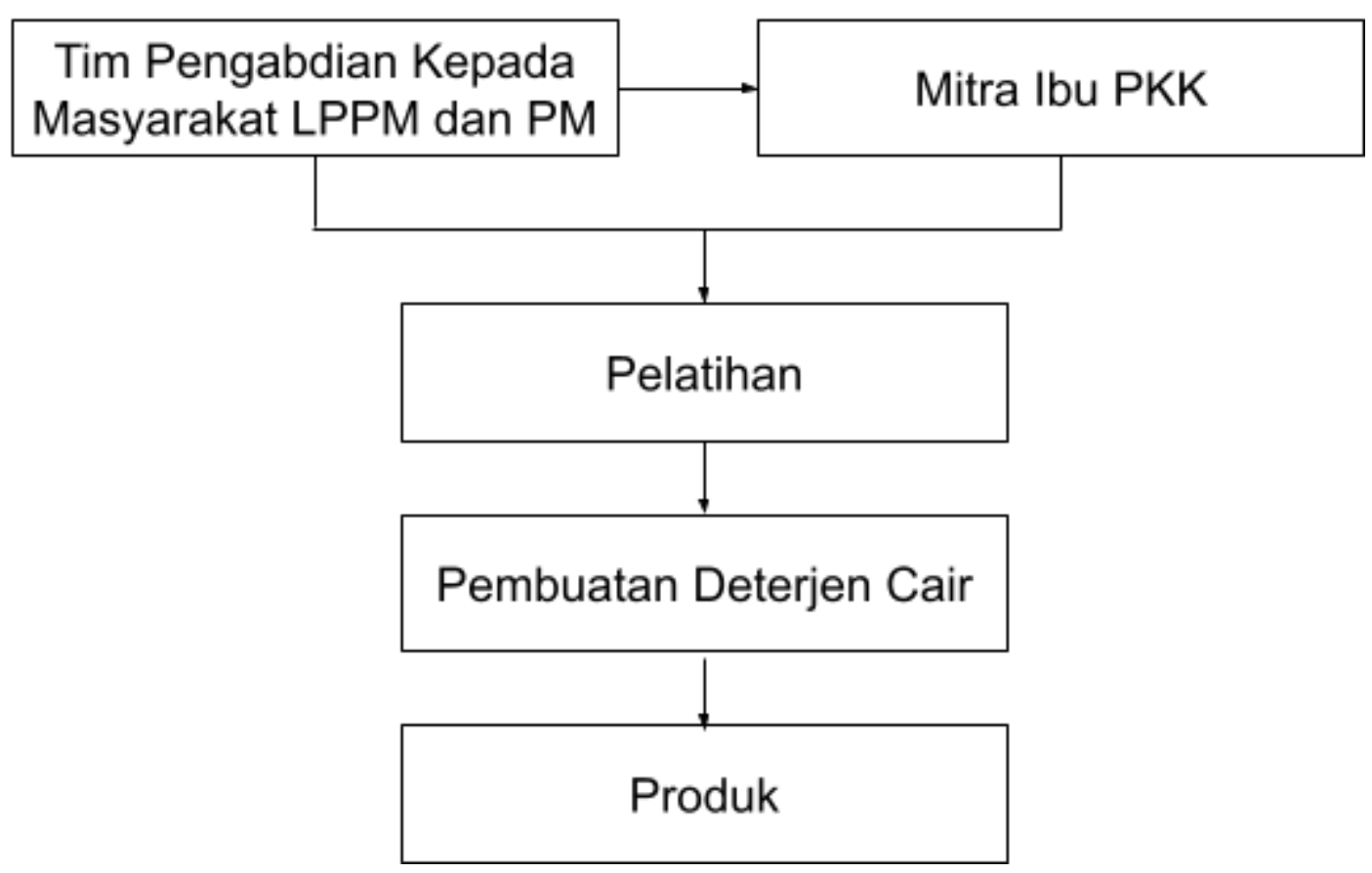

Gambar 1. Rancangan Pelatihan Pengabdian Kepada Masyarakat

Pembuatan deterjen cair menggunakan alat meliputi; (a) tong air; (b) ember; (c) saringan; (d) pengaduk; (e) gelas ukur; (f) botol; (g) label kemasan sedangkan bahan meliputi; (a) texapon; (b) deterjen pasta; (c) pencerah pakaian; (d) pembersih noda; (e) gincu; (f), filter; (g) parfume.

\section{Hasil}

Hasil dari kegiatan yang telah dilaksanakan oleh tim pengabdian dengan memberikan pelatihan kepada ibu PKK Gampong Sungai Pauh Pusaka, terdapat beberapa tahapan sebagai berikut, yaitu (1) Tahap Survey Lokasi, pada tahap ini tim pengabdian melakukan survey kelapangan untuk melakukan kerjasama dengan pihak yang dijadikan mitra pengabdian. Hal yang dilakukan terjadi kesepakatan tim pengabdian dengan ibu PKK Gampong Sungai Pauh sebagai mitra. Dengan demikian terjadilah sosialisasi serta kesepakatan penentuan jumlah peserta dan jadwal kegiatan. 


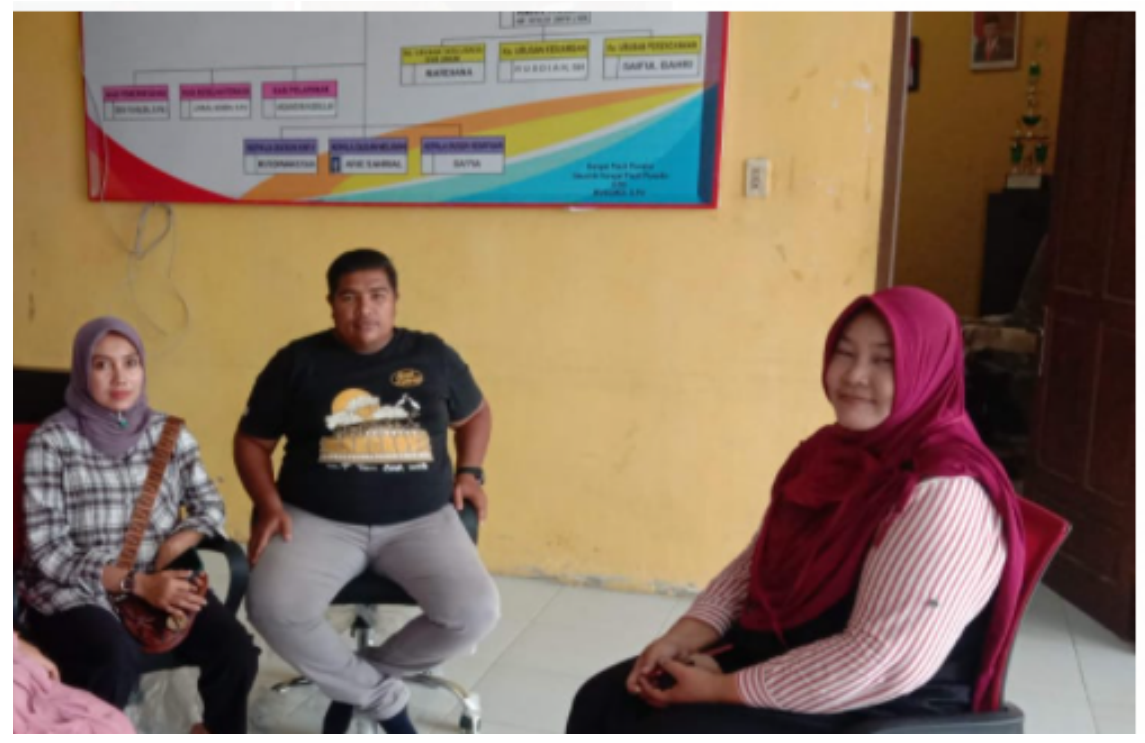

Gambar 2. Tahap Survey Lokasi

(2) Tahap Pelatihan, adapun yang menjadi langkah - langkah dalam kegiatan pengabdian oleh tim pengabdian dengan mitra, dapat dijelaskan seperti (a) persiapan, pada tahapan persiapan tim pengabdian terlebih dahulu menjelaskan fungsi dan manfaat deterjen cair dan juga menjelaskan alat dan bahan yang digunakan untuk pembuat deterjen cair. Alat dan bahan ini disiapkan oleh tim untuk mitra. Dapat dibuktikan pada gambar 2 dibawah ini.

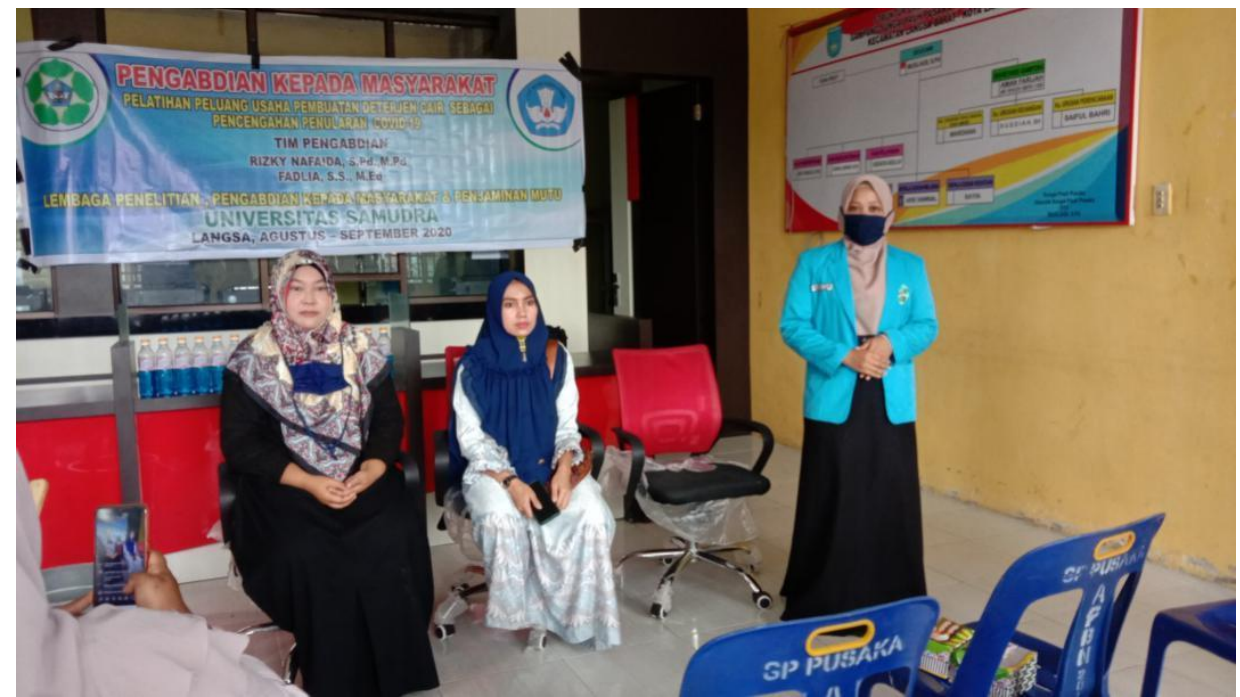

Gambar 3. Tahap Persiapan Pelatihan

(b) pembuatan, pada tahap ini tim pengabdian dengan mitra sama - sama membuat deterjen cair dapat dipaparkan yaitu (1) isikan air kedalam ember sebanyak 18 liter; (2) masukkan bahan texapon diaduk sampai rata berwarna putih bersih; (3) masukkan bahan deterjen pasta diaduk sampai rata serta didiamkan selama 1 jam; 
(4) selanjutnya masukkan bahan pencerah pakaian; (5) masukkan pembersih noda sambil diaduk dengan rata sehingga semua bahan tercampur; (6) tahap berikut masukkan filter sedikit demi sedikit agar bahan menjadi kental; (7) tutuplah bahan yang telah tercampur semua, diamkan semalaman; (8) keesokkan harinya masukkan gincu dan pewangi pakaian.

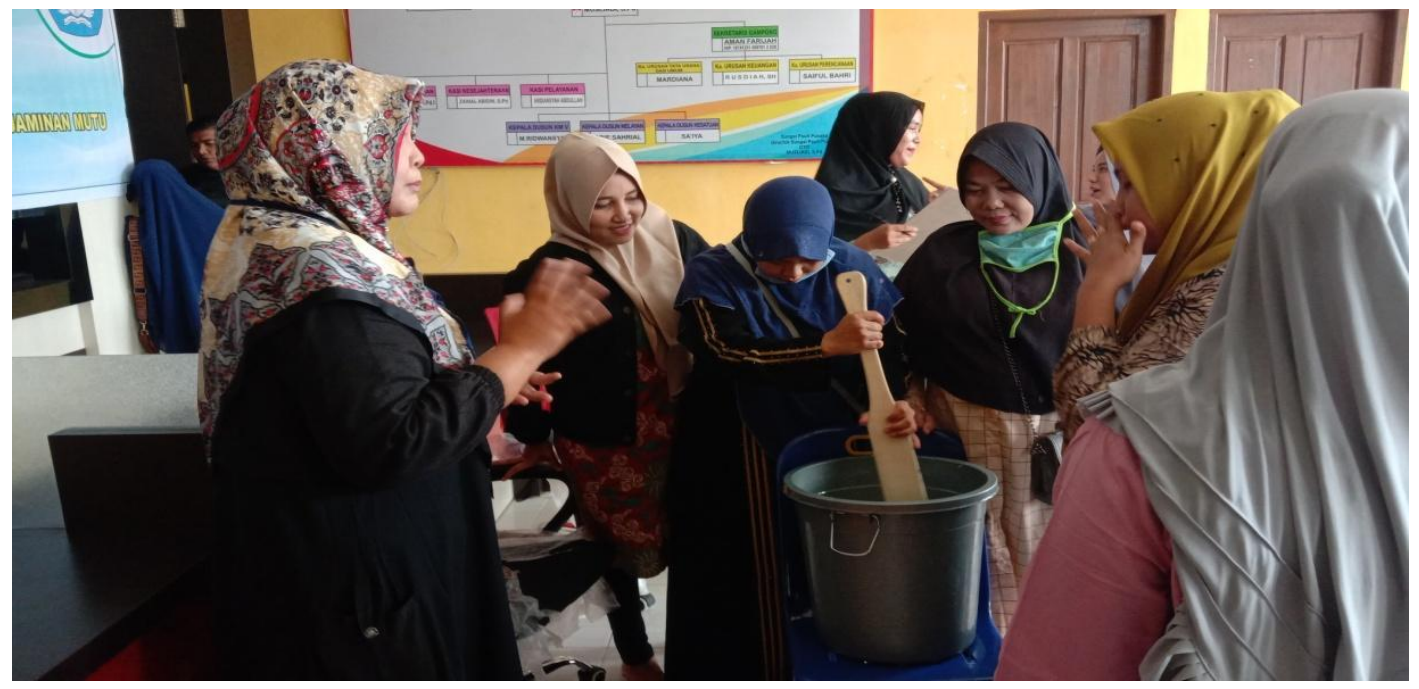

Gambar 4. Tahapan pembuatan deterjen cair

(c) pengemasan, produk yang sudah dibuat dengan proses pengendapan semalaman, maka selanjutnya dilakukan tahapan pengemasan kedalam botol. Produk yang telah jadi diberikan kepada masyarakat khususnya kepada ibu PKK.
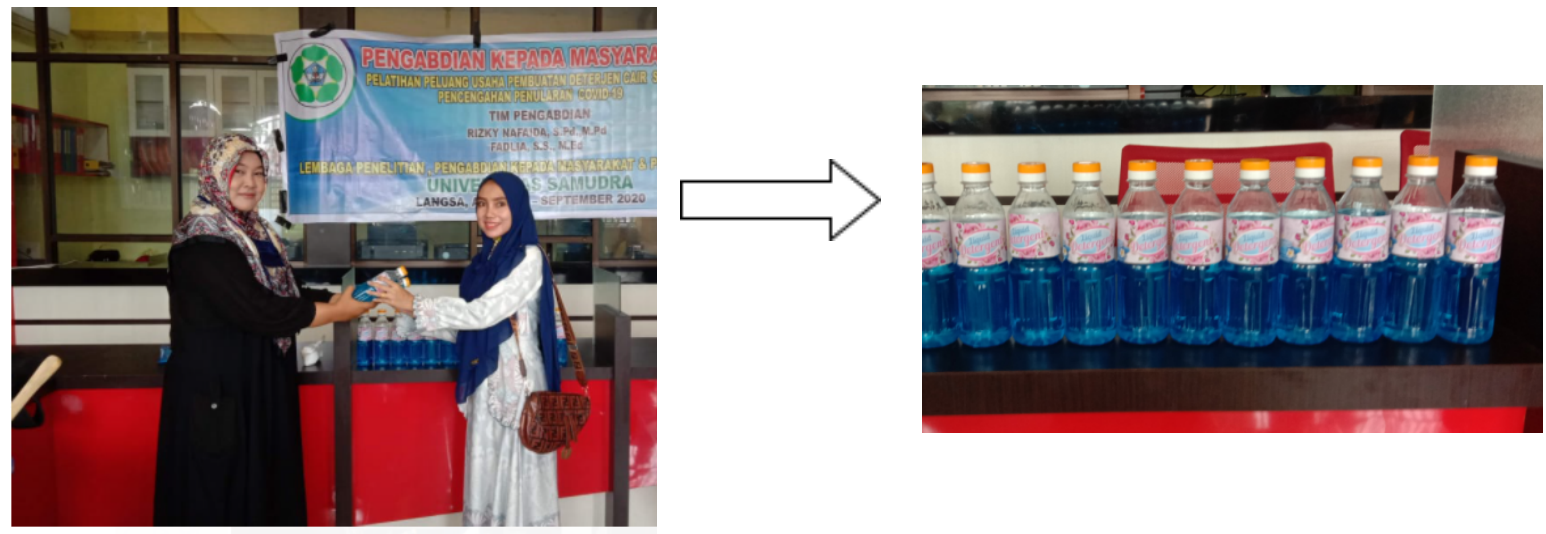

\section{Gambar 5. Produk Deterjen Cair}

(3) Tahap Monitoring dan Evaluasi, pada tahap ini tim pengabdian melakukan penyebaran angket kepuasan kepada Ibu PKK Gampong Sungai Pauh Pusaka. Penyebaran angket ini untuk mengetahui kepuasan lbu PKK dari hasil pelatihan pembuatan deterjen cair pakaian. Adapun angket yang dibuat menggunakan skala Likert dengan pilihan jawaban 1-4 (1= sangat tidak puas; 2=tidak puas puas; 3= puas; 4=sangat puas). Angket ini diberikan kepada 20 orang jumlah peserta kegiatan. Untuk mengetahui hasil dari penyebaran angket dapat dilihat pada tabel 1. 
Tabel 1. Tingkat Kepuasan Ibu PKK Gampong Sungai Pauh Pusaka dari Kegiatan

Pelatihan Pembuatan Deterjen Cair

\begin{tabular}{|c|c|c|c|c|}
\hline No. & Uraian Pernyataan & Jumlah & Rata-rata & Keterangan \\
\hline 1. & $\begin{array}{l}\text { Bagaimana menurut pendapat Ibu } \\
\text { Program Pengabdian kepada } \\
\text { Masyarakat (PKM) }\end{array}$ & 17 & $85 \%$ & $\begin{array}{c}\text { Sangat } \\
\text { Puas }\end{array}$ \\
\hline 2 & $\begin{array}{l}\text { Materi proses pembuatan deterjen cair } \\
\text { pakaian pelaksanaan program PKM } \\
\text { memberikan pengetahuan }\end{array}$ & 16 & $80 \%$ & Puas \\
\hline 3 & $\begin{array}{l}\text { Pelaksanaan program memberikan } \\
\text { keterampilan bagi lbu - Ibu dalam } \\
\text { peluang usaha }\end{array}$ & 17 & $85 \%$ & Puas \\
\hline 4 & $\begin{array}{l}\text { Personil/anggota yang terlibat dalam } \\
\text { kegiatan pengabdian masyarakat } \\
\text { memberikan pelayanan sesuai dengan } \\
\text { kebutuhan saya }\end{array}$ & 19 & $95 \%$ & $\begin{array}{c}\text { Sangat } \\
\text { Puas }\end{array}$ \\
\hline 5 & $\begin{array}{l}\text { Setelah pelaksanaan program PKM } \\
\text { akan dilanjutkan lagi untuk membuat } \\
\text { produk ini }\end{array}$ & 14 & $70 \%$ & Puas \\
\hline \multicolumn{2}{|c|}{ Jumlah Rata - Rata } & 83 & $83,0 \%$ & Puas \\
\hline
\end{tabular}

Berdasarkan hasil kegiatan pengabdian yang telah dilaksanakan oleh tim pengabdian dengan memberikan pelatihan kepada ibu PKK Gampong Sungai pauh Pusaka. Kegiatan ini didukung dengan Standar yang mengatur tentang deterjen cuci cair mutu teknis adalah Standar Nasional Indonesia (SNI) 06-4075-1996, Deterjen serbuk mutu teknis (Nasional, 2017). Pada SNI 06-4075-1996 ini, diatur syarat mutu dan cara uji untuk deterjen cuci cair mutu teknis yang dipakai pada berbagai industri dan kosmetik, tetapi tidak termasuk deterjen cuci cair untuk bahan pangan. Salah satu parameter yang dipersyaratkan adalah kadar dari surfaktan anionik minimal sebesar dari 15\% - 35\%. Hasil tersebut menggambarkan bahwa kegiatan pengabdian yang dilakukan dapat dinyatakan berhasil, hal ini ditunjukkan adanya kesadaran lbu PKK tentang pentingnya hidup produktif dan mandiri melalui berwirausaha (Hunaepi et al., 2017). 


\section{Kesimpulan}

Pada tahap survey dimana tim pengabdian disambut dengan baik, setelah terjadinya diskusi untuk melaksanakan kegiatan pelatihan pembuatan deterjen cair. Pada tahap pelatihan tim pengabdian dan mitra sama - sama membuat deterjen cair sedangkan pada tahap monitoring dan evaluasi tim pengabdian melakukan penyebaran angket kepuasan. Hasil yang diperoleh pada tahap ini dengan nilai 83,0\% dinyatakan puas ibu PKK Gampong Sungai Pauh sebagai mitra akan melanjutkan produksi deterjen cair sebagai usaha rumah tangga.

\section{Pengakuan/Acknowledgements}

Kegiatan pengabdian merupakan dana DIPA Unsam maka tak lupa pula tim pengabdian mengucapkan terima kasih kepada Lembaga Penelitian, Pengabdian Kepada Masyarakat \& Penjaminan Mutu Universitas Samudra yang telah memberikan dana, sehingga kegiatan ini berjalan dengan lancar.

\section{Daftar Referensi}

Hunaepi, H., Samsuri, T., Firdaus, L., Mirawati, B., Ahmadi, A., Muhali, M., Asy'ari, M., \& Azmi, I. (2017). Pemberdayaan Ibu-Ibu PKK Melalui Pelatihan Produksi Deterjen Cair di Desa Sukaraja Lombok Tengah. Lumbung Inovasi: Jurnal Pengabdian Kepada Masyarakat, 2(1), 65-67. https://doi.org/10.36312/linov.v2i1.416

Nasional, B. S. (2017). Detergen cuci cair - Bagian 2: Untuk alat dapur (438/KEP/BSN/12/2017; SNI 06-4075-1996, Deterjen Cuci Cair).

Ramaswamy, J., \& Veenstra, J. N. (1995). Treatment of wastewater from an oil refinery sour water stripping unit using an aerated submerged biological filter (CONF-9509296-). USDOE, Washington, DC (United States); Amoco Production Co., Houston, TX (United States); Conoco, Inc., Stamford, CT (United States). https://www.osti.gov/biblio/377171

Rosariawari, F. (2008). Penurunan Konsentrasi Limbah Deterjen Menggunakan Furnace Bottom Ash (FBA). Jurnal Rekayasa Perencanaan, 4(3), 1-12.

Utomo, W. P., Nugraheni, Z. V., Rosyidah, A., Shafwah, O. M., Naashihah, L. K., Nurfitria, N., \& Ullfindrayani, I. F. (2018). Penurunan Kadar Surfaktan Anionik dan Fosfat dalam Air Limbah Laundry di Kawasan Keputih, Surabaya menggunakan Karbon Aktif. Akta Kimia Indonesia, 3(1), 127. https://doi.org/10.12962/j25493736.v3i1.3528 